\title{
The Issues of Unclaimed Properties in Malaysia
}

\author{
Wan Zahari Wan Yusoff ${ }^{1 *}$, Muhammad Azwan Sulaiman ${ }^{2}$
}

${ }^{1}$ Faculty of Technology Management \& Business

Universiti Tun Hussien Onn Malaysia, 86400 Parit Raja, Johor, MALAYSIA

${ }^{2}$ Faculty of Architecture, Planning \& Surveying

University Technology Mara (UiTM), 40450 Shah Alam, Selangor, MALAYSIA

*Corresponding Author

DOI: https://doi.org/10.30880/jstard.2021.03.02.002

Received 10 May 2021; Accepted 22 June 2021; Available online 15 December 2021

\begin{abstract}
Unclaimed property in Malaysia has become one of the more hotly debated issues. So far unclaimed property value estimated to reach billions of ringgit. This is a big number, and, if issues stay no action has taken, it will affect not only the society but also economic and national development. If the efficient property management system had to be set up it will have undoubtedly a positive impact. Therefore, there is a need to take a drastic action to find a comprehensive solution and alternatives for solving this issue. Hence, an effective asset management and an efficient estate planning towards unclaimed property must be practiced to ensure a smooth operation of the property management. Generally, unclaimed property is divided into two main categories. Firstly, the inherited estate from a deceased that is not claimed by the heirs and another one is the property the owner of which cannot be traced or missing, known as Al-Mafqud in Islamic law. In this paper, the researcher has focused on the occurrence of unclaimed property in the context of missing persons. The results of this study are based on data gathered through a grounded theory from few agencies such as the Malaysian Civil and Shariah Courts, Small Estate Distribution Unit in the District Land Office and Amanah Raya Berhad as well as the heirs of missing persons. The information of missing person's heirs collected from Royal Malaysia Police (RMP) and the information clarified as confidential. In general, the result shows that, there are for factors contributed to the issues of unclaimed properties in Malaysia; legislation, social status, behavior and the strength and weaknesses of related agency should be given consideration. This results are expected to be catalyst to further action by the government to solve the issue of unclaimed property in Malaysia and concurrently contribute to enhance the quality of property management based on highest and best use concept.
\end{abstract}

Keywords: Unclaimed property, missing person's property, property management, factor and issue

\section{Introduction}

Malaysia is one of the leading developing countries and aims to achieve a high-income nation status. Thus, an appropriate approach needs to be recognized in order to plan and manage the billion Ringgit worth of assets. Shariah Judiciary Department of Malaysia is seeking for a solution on how to manage the issues of unclaimed assets [1]. The wealth and assets which are valuable owned by Muslims can be used for development and should be utilized for the glory of Islam in this country [2]. Hence, it is expected to solve the issues and problem regarding frozen private properties worth billions of Ringgit. These valuable assets have a very high potential to generate income for the development of the Muslim community and improving economic status of Malaysians.

The missing person's property is not a new issue in Malaysia. In Islamic perspectives, a missing person is known as 'Al-Mafqud' which means the person's whereabouts or his status as being alive or dead is unknown. In 2013, the value of missing person's property was estimated to be RM66.6 billion still unclaimed [1]. These issues gives a negative impact to the heirs, religion, country and society, but people generally disregard this issue. However, this issue 
has been debated since Malaysian MH 370 missing tragedy on 8th March 2014. Until today, there is no conclusion regarding this tragedy. On 29th January 2015, Malaysian Government declared MH370 is an accident and all passengers and crews are presumed dead. MH370 issue is just a tonic to tell the public about the importance for property management of Al-Mafqud. Although the issue seems small, however the impact is enormous. The uncertain status affects the property of the missing persons. The problem is the property of Al-Mafqud or his estate will freeze.

The freeze period ends once Al-Mafqud or the heirs come to claim. However, in certain cases, heirs are not aware about these issues. The situation gets worse when there is a family dispute, because no one even knew the family background of Al-Mafqud. Currently in Malaysia, the government has no right to liquidate the unclaimed property for a given period of time. Besides the Civil law restrictions, the Shariah Law does not allow unfreezing the property without any strong reason. However, the National Fatwa Committee in 1982 has decided that the government has the right to acquire or use any form of property that is not used for public interest [2]. But The Decision cannot be considered the text of the law, rather it is just a guideline. That means, base on it, the government should take action to solve the problem. In this paper we are focusing on the analysis of issues related to property management from perspective of mafqud in Islam. The concept of property in Islam should be understood as providing a best solution suited to the nature of Muslim as it is a blessings to all mankind. The issue of inheritance of Al-Mafqud may be related to the Islamic Law of Inheritance, which is considered part of the estate or (al-tarikah) left by the deceased, something that is not unanimously agreed by all jurists of Islamic jurists [3].

\section{Literature Review}

\subsection{Property In Islamic Perspective}

Wealth is a trust by Allah S.W.T and given to humans as a symbol of wealth in the world. Human received the wealth from God and it is a right to use it and disburse it to the beneficiary through an organized way recognized under Islamic law. Thus, the administration and management of property in Islam are emphasized with reference to the established concept and rules or laws [4]. The wealth is a temporary gift from Allah S.W.T as an award to achieve a blessed life. However, property with wise management is contradicting with the Islam way [5].

In Islam different categories are given to wealth which are Mutaqawwan (useful things), Ghair Mutaqayyam (unuseful things, Mithy (same value at any place), Qimmi (different value with different place and situation), Manqul (mobile asset), Ghair Manqul (immobile asset)[6]. The immoveable property is Ghair Manqul also known as A'aqar (intangible asset).

The concept of A'aqar covers all the things that exist on the surface of the earth, such as buildings, water, vegetation and mineral resources that exist under it. Property in Islam has its own unique concept contributed by various scholars of Islam which may be treated as opinions, and estimates. However, despite the different aspects of assessment, goal and purpose all are still the same. There are two key features in determining property in Islam [7];

- An object that can be stored and collected which can be used as a right.

- Objects that can be taken advantage of and derive benefit therefrom.

Freezing property or monopoly by certain parties is a condition that is rejected by Islam because it can cause a variety of harmful effects on society and the country. With reasonable care of the property administration system according to Islam, the circulation of wealth will occur in a healthy and harmonious manner. But by itself, the inherent value of the property can be maximized through direct use or investments. This situation certainly can improve the lives of Muslims or country. History also shows that the law serves as the basis for establishing a justice that exists along with the existence of a society. The existence and application of this law affected sentiment and understanding, customs, religion, culture and many others. It begins in a relatively simple form and grows to be a complex one [8].

\subsection{Property in Maqasid Syariah}

Maqasid Shariah have generally been a chain of five basic principles of Islam as stated by Imam Al-Ghazali which are the legal objectives of Shariah, include the Protection of wealth (hifz al-mal). It is one of the requirements of human life and human beings who cannot be separated from it. Islam does not prevent the human search for treasure as much as possible provided one can do it and does not violate Islamic law. This is consistent with human desire to maintain the property in order to increase the degree and the pleasures of the world. However, in fact that all wealth belongs to Allah, but Islam also recognizes the right of a private person [8]. Therefore, man is obsessed with wealth, and working through the various roads set by Islam to avoid chaos within each other.

\subsection{Al-Mafqud And Concept}


A. Definition of Al-Mafqud

The definitions of a missing person or Al-Mafqud are:

- It does not look or sound significantly, [9]

- Cause to disappear does not appear again, and wipe himself [9]

- Eliminated but not known whether alive or dead [9]

Al-Mafqud is defined as someone who is lost from a place for a long period without news and no one knows about him and is also unknown whether he is still alive or had passed away [10]. Another scholar defines Al-Mafqud as someone who is lost from some place without any news and his status is unknown [11]. According to the Estates of Missing persons Act 1996 of Canada, a missing person is a person who lives in a place where relatives of the person who knows him, and who might hear the news, are unable to hear any news from him, at least for 3 last month [12]. Whereas according to the Estates of Missing persons Act (management) 1973 Uganda he is being a person who disappeared without making reasonable provision for the administration of his property. if any, and they disappeared without the news in the last six months, any relative of a missing person may, with the consent of the family, ask the court to issue commands to manage the property, but the court may, if it deems necessary or desirable, give orders to more than a heirs to manage the property together [13].

\subsection{Period To Wait For Al-Mafqud To Be Presumed Dead In Malaysia Syariah And Civil Law}

The legal system in Malaysia is divided into two, namely Shariah and Civil law. Each law, not just have different period for presumed of death, but also have different functions.

\section{Civil Law}

Regarding the section 108, Evident Act 1950, the period for Al-Mafqud to be presume as dead is 7 years and can be declared by the Civil High Court and above. Only the presumption of death or Death Declaration from Civil court can be used by the heirs in claiming inherence [14].

\section{Syariah Law}

Shariah law is legislative jurisdiction of the state government. All states in Malaysia (except Terengganu) insert in their Shariah law that the waiting period for presumption of death to be 4 years. However, the function of presumption of death from the perspective of Syariah Court in matters relating to the dissolution of marriage, is not valid for property claims.

\subsection{Civil vs Syariah Law in Malaysia}

Article $121(1 \mathrm{~A})$ of the Malaysia Federal Constitution states the Civil Court has no jurisdiction over matters falling within powers of Shariah Court [15]. Amendment of Article 121 of the Constitution in 1988 showed that the existence and integrity of Shari'a law has been recognized by the Federal Constitution and the Syariah Courts now have the absolute power to decide and resolve cases or some things that are under its jurisdiction. This means that the civil court can no longer talk about a case that is under the jurisdiction of the Syariah Court. The purpose of this change is because there are some cases in which the civil courts had previously discussed certain matters even the basic thing in this case was under the jurisdiction of the Shariah Court. Thus, these changes are expected to be the solution to disagreements which arise and clarify the division of jurisdiction between the two courts.

The amendments have given special status to the Shariah Court. The greatest theoretical effect of this change would be prevention of a conflict between Shariah court decisions and that of the civil court. As it happened in some previous cases involving custody of children cases, matrimonial property, and illegitimacy of children at the Civil High Court, it did not decide in accordance to Islamic law. This upset the Muslim parties who felt it was harmful. On the other hand, the Civil High Court decision in favor of the law contrary to Islamic law. Civil courts have also made decisions on matters within the jurisdiction of the Shariah Court and sometimes have to change a decision made by the Shariah court. With this amendment the difference between the Civil Court and Syariah Court should not occur again because the matter can only be brought to the Syariah and Civil courts no longer have jurisdiction. Therefore, this problem can be solved. The jurisdiction of the two courts, ought to run as their track as in the constitution and should not exercise powers that are not given them by the Constitution.

\subsection{Issues in The Property Management Of Al-Mafqud}

On the issue of ownership before somebody is Al-Mafqud, or property acquired during his disappearance, the property cannot be distributed among the heir or nominated until there is death confirmation such as a death certificate produced or after court declaration after certain period. The period is not fixed, but will depend on the judge to confirm his death. Before grant of probate transaction in any property is illegal because the Al-Mafqud is still assumed alive. 
The property can also not be inherited. After the judge confirmed his death his property passes to the persons who are entitled to receive it perhaps in accordance with principles of Islamic law.

\section{A. Inheritance of Al-Mafqud's Property}

Inheritance means property belonging to the legal heirs or the estate and inheritance [16]. While the heir is the party entitled to receive an inheritance from a person who had died. In the inheritance of Al-Mafqud, there are two conditions, namely [16];

1. Al-Mafqud as person who inherit property (muwaris).

2. Al-Mafqud as an heir entitle to inherit the property.

\section{B. Al-Mafqud As Muwaris}

After the court issues an order for the presumption of death of Al-Mafqud, the property can be inherited by his family in accordance with the command of Allah in the Qur'an. However, before the property can be distributed to those who are nominated, something should be done by the heirs in advance, that is observing the order of priorities. The rights related to the estate are divided into five (5) namely;

1 . The rights to the any asset and property,

2. The right to claim the funeral expenses of the deceased,

3. The right to settle the debt.

4. Execute a will.

5. Distribute the remaining inheritance to the heirs according to the fara'id law.

\section{The Right of Al-Mafqud to Inherit from Others}

Al-Mafqud will still be considered alive as long as there is no evidence, or proof of his death or until the judge does not confirm his death. Based on this principle he is entitled to inherit until his death is confirmed; and if there are heirs who will not receive an inheritance in one assumption, this heir cannot inherit the estate because there is a possibility that the missing is still alive.

\section{Research Methodology}

The researcher has chosen to use a qualitative data. Qualitative investigation aimed at understanding the social problems based on extensive research process, established by the revelations, and from situations that are natural [17]. Various researchers argue that a qualitative approach is used when a researcher wants to understand the point of view of the respondents in more depth and dynamic manner. Additionally, researcher considers qualitative research to be descriptive research, where researchers focused on aspects of the process, the intent and understanding of subjective experience and appreciation of the respondents.

A qualitative approach was used in the research process that requires in-depth exploration of a particular phenomenon. In this case, grounded theory is used to achieve the objectives of this research. It is because of this research that is fundamental and involves social behavior in diverse communities. Grounded theory method is also suitable for use in a study in the same scope of the study has limitations such as theoretical frameworks, models and review of the literature on asset management of Al-Mafqud.

\section{Result and Discussion}

Based on the results of this study it is established that the causes of freezing property of Al-Mafqud in Malaysia is due to the two sides of the heirs and the authorities. Although the legal aspects are seen as the main factor, however, there is still some chance which can be used by both parties to avoid freezing property. This is shown as Figure 1.

The study also found that courts can still order liquidation of real estate of Al-Mafqud. But ambiguity in context of specific legislation is a major consideration. The court order is just an opportunity to explain the rational for such a property is withdrawn, and not a special warranty. In the current situation, the risks are very high that the conflict of jurisdiction may arise on the issue of mafqud status. Thus, a new law may be required like that in the United States, Canada, Australia, Ireland and Uganda for solving such issue. 


\begin{tabular}{ll}
\hline LEGISLATION & \multicolumn{2}{l}{ SOCIAL STATUS } \\
$-\quad$ Conflict of Law & $\bullet \quad$ Financial Resources \\
$-\quad$ Provision of Law & $\bullet \quad$ Knowledge \& Education \\
\hline $\begin{array}{l}\text { BEHAVIOUR } \\
\text { - Level of Awareness }\end{array}$ & WEAKNESSES OF AGENCY \\
\hline
\end{tabular}

Fig. 1 - The factors contributing to the Al-Mafqud unclaimed properties

Information about the law in matters relating to the management and administration of real estate Al-Mafqud should be the focus of the government. Muslims in Malaysia are generally very sensitive where government's actions are contrary to the shariah law. Diplomacy approach should be taken in explaining for this issue.

The factors such as sentimentality and family relation must be addressed wisely among the heirs. Although they have right to the properties. The next of kin ought not to figure out these family issues within the framework of the narrow and personal interests. The bigger issue should be viewed as a waste of resources would occur without solution. Then, on the issue of ownership before a person goes missing, or property acquired during his disappearance, such property cannot be distributed until after his death is confirmed or the disappearance takes place over such a period of time where usually the missing person cannot be presumed to be living beyond that period. Duration of time is not automatic rather an order of court is still needed to confirm the death of the missing person. Any time before the judgment, the missing persons is still presumed alive and the property cannot be Besides, there is the issue of weakness of agencies and the lack of service delivery to the society. For the agencies to resolve the problem, it is proposed, that they need more authority to improve their service. Currently, although each agency involved does not have a special responsibility for matters relating to Al-Mafqud, but they should take initiative in order to serve the society by campaigning and educating the public. Furthermore, a special agency to administer the property of Al-Mafqud is very important to setup and the authorities should look at this matter seriously in order to avoid the worst of society and country.

\subsection{Benefit The Property Management Of Al-Mafqud}

A number of advantages can be achieved when the Al-Mafqud property can be used by the society and also the development of the nation because a large portion of property can be used productively. Without the proper strategy for the management of Al-Mafqud property, the country may suffer high losses. Following are the advantages that can be achieved through proper management of Al-Mafqud property:

\section{Eradication of Poverty}

A majority of the indigents consists of Muslims. This group looks so weak that their needs lead them to social, educational and other problems. Property owned by Al-Mafqud can be developed in such a way that could cause eradication of poverty among Muslims. Payment of zakat from Al-Mafqud property and the involvement of the indigent in the development of the property of Al-Mafqud will create jobs that may be solve problems thereby bringing a harmonious society.

\section{Education}

The formation of human capital in Islamic societies is crucial to ensure continuity and sustainability of Muslim communities. Various programs such as scholarships, establishment of religious schools, the construction of the universities and short courses can be financed if the property of Al-Mafqud can be defrosted and used towards the better development of human capital.

\section{Economy}

The economic power of the Muslim community is not strong as it should be despite being a majority in Malaysia. Equity holdings in property including company shares by the Muslim community is still weak. Economic empowerment of Muslims is crucial and with the use of proper management of Al-Mafqud property, it may be achieved. 


\section{Conclusions}

The differences of perspective in Islam of duration of Al-Mafqud have been discussed. Undeclared status of AlMafqud affects the property distribution to the heirs and unclaimed property due the status of Al-Mafqud can be useful if the property can be utilized for society especially for development of society. The advantage of property of AlMafqud property also have been presented where it can provide benefit to the poor, education and the economy. Moreover, the management of Al-Mafqud properties can be introduced in order to effectively utilize the property. Government should play a big role as well as draft a special law on Al-Mafqud property management as already done in a few countries in the world.

\section{Acknowledgement}

This work was supported by Universiti Tun Hussein Onn Malaysia (UTHM) and the writers express their profound gratitude to them for the opportunity.

\section{References}

[1] Malaysia Syariah Judicial Department Report 2013.

[2] Ibrahim lembut, Al-Mafqud Real Problems according to Shariah law in the Malaysian Perspective, PhD, State Islamic University Pekan Baru, Indonesia.

[3] Mohd Zamro Muda Awang and Mohd Ridzuan, Islamic Inheritance Law Implementation in Malaysia, Bangi: Shariah Department, Faculty of Islamic Studies, Universiti Kebangsaan Malaysia. m / s. 2. (2006),

[4] Muhammad Ali Ash-Shabuni, Allocation According to Waris Islam. Sooriya printing, (1996).

[5] Amir Bahari. Q Will Islam. The National Library of Malaysia. Telaga Biru. Ltd. (2012).

[6] Wahbah al-zuhaili, Fiqh al Islami waa dillatuhu, Damsyik: dar al fikr (1984).

[7] Abd al-Karim al-Khatib al-Siyasah al-maliyah fi al-Islam wa al mucamalah silatuha bi wa al-mucasarah, Dar al- Fikr al-Arabiy, Cairo, 1976M / 1396H hlm.29.

[8] Shaykh Muhammad al-Tahir Ibn Ashur (2006), Maqasid al-Sharia al-Islamiah, Tunis: Dar al-Islam.

[9] Dewan Bahasa Dan Pustaka fourth edition (2012)

[10] Mustafa al-Khan, et al, 'Fiqhul Manhaji', the second volume, sixth printing, Printing Darul Qalam, Damascus, Syria, on page 331, (2005),

[11] Wahbah al Zuhaili, Fiqh and Islamic Jurisprudence Volume 1V, translated by End Yaacob Md at.al and original book al-Fiqh al-islamiwa Adillatuhu al-Jul al Thani, Dewan Bahasa Pustaka, 1996

[12] Estates of Missing Persons Act 1996 of Canada

[13] Estates of Missing Persons Act (management) 1973 Uganda

[14] Section 108 of Act 1950 of Malaysia Evident

[15] Article 121 (1A) of the Federal Constitution

[16] Abdul Rashid et al (2013) Property Management Through Grants: The Importance And Benefits Of Various Aspects for the Development of Ummah Jurnal Hadhari 5 (1) (2013) 91-104

[17] Creswell, W. J. (1994). Research Design, Qualitative, Quantitative, and Mixed Methods Approaches.1st.ed. London: Sage Publications 